\title{
Investigating the Changes of Total Organic Carbon Content in Bottled Water Under Environmental Stress Conditions
}

\author{
Sepideh Daghigi Masouleh, Fuad Shirmahi, Hossein Ghafourian, Mohammad Taghi Sadatipour \\ Department of Environmental Engineering, Faculty of Marine Science \& Technology, Islamic Azad University, Tehran, Iran \\ Email address: \\ h_ghafourian@iau-tnb.ac.ir(H.Ghafourian) \\ To cite this article: \\ Sepideh Daghigi Masouleh, Fuad Shirmahi, Hossein Ghafourian, Mohammad Taghi Sadatipour. Investigating the Changes of Total Organic \\ Carbon Content in Bottled Water Under Environmental Stress Conditions. American Journal of Environmental Protection. \\ Vol. 7, No. 1, 2018, pp. 14-18. doi: 10.11648/j.ajep.20180701.13
}

Received: February 6, 2018; Accepted: February 25, 2018; Published: March 29, 2018

\begin{abstract}
The consumption of bottled drinking water has increased considerably in the recent years. The main objective of this study was to investigate the changes of total organic carbon (TOC) level in bottled water under various environmental stress conditions. In this study, samples of drinking water were taken just before and after bottling process from three mineral water bottling plants in Tehran province, and the comparison of the levels of TOC content of the water was evaluated before and after bottling process, and at the end of the consumption period. The results indicate that TOC level in mineral water increases over time. There were very few changes of TOC level in the bottled water after one day. After one month and then three months, the changes became more significant in a way that the TOC level increased from 1.6 to $2.33 \mathrm{mg} / \mathrm{L}$. Studying the bottled waters just few days left to their expiration dates revealed that the level of TOC increased twice, i.e. from 1.6 to 2.9 $\mathrm{mg} / \mathrm{L}$. Also, the level of TOC in samples changed significantly one month after the expiration date, and it increased from the initial 1.6 to $3.2 \mathrm{mg} / \mathrm{L}$. The level of TOC in samples exposed to sun was almost four times more, and reached its highest level of $5.47 \mathrm{mg} / \mathrm{L}$. Also, the level of changes in samples after freezing increased from initial 1.6 to $4.11 \mathrm{mg} / \mathrm{L}$.
\end{abstract}

Keywords: Bottled Water, Organic, Compounds, TOC

\section{Introduction}

Consumption of bottled drinking water has increased considerably in the recent years (Zandvakili et al., 2005). This increasing trend is probably due to the consumers' perception of the good quality and safety of bottled waters (Ali Mohammadi, et al., 2013; Loloei, etc. 2009). The research on the quality assessment of bottled water has a long history and includes a variety of fields [1]. Polyethylene terephthalate (PET) bottles can affect the chemical properties of water inside the bottle over time [2]. These effects can include the migration of mineral or organic compounds as well [3]. Storage conditions can affect the severity of these changes [4]. Organic compounds released from these containers can result in the potential risk of poisonous contents for genes, negative effects on endocrine system and cancers [5]. Unfortunately, there has not been a proper study in this regard in Iran. Careful examination of the organic materials is a time consuming and costly process [6]. Instead of measuring the water in parts, the level of TOC changes can be measured [7-10]. Therefore, this study tries to measure the changes resulting from the organic materials of PET bottles in the water at the time of production, after three months from the production date and under different light and temperature conditions.

\section{Materials and Devices}

TOC test can be conducted in both online and offline manners using the calibrated equipment in the laboratory. The accuracy and correctness of the tools should be evaluated periodically in accordance with the following procedure. Also, it is necessary for the device to be able to detect values less than or equal to $0.05 \mathrm{ppm}$ of carbon. The amount of TOC was measured using a spectrophotometer. The unit of this variable was considered as $\mathrm{mg} / \mathrm{L}$. The recommended level for this variable in refined water is 2 mg/L (TCEQ, 2002; Mamba, et al., 2008).

The sample size of the study was 2.5 liters according to the TOC instructions put forth by the department of water 
resources of the Texas Commission on Environmental Quality (TCEQ, 2002). The number of samples was determined according to the available facilities and with the assumption that some slight changes might occur in the volume of input water to the process and using the description of the sampling plan contained in the TOC guidelines of the water resources department of the TCEQ (2002).

\section{Sampling}

This study used standard volumes of samples (at least 0.5 liter) from water bottling plant according to the standard methods of sampling (11). Then, using a combination of methods utilized in the studies of Joneidi et al. (3) and Ali Mohammadi et al. (5), the bottles were exposed to environmental stress for a maximum period of three months. At the end of the TOC test, the standard procedure (1) was followed.

In order to investigate the effects of the mentioned factors on TOC contents of the bottled waters during the period of consumption, three water samples were taken immediately before and after the bottling process from three water bottling plants (Damavand, Nestlé Pure Life, Aquafina) and their TOC levels were measured. Then, five water samples were selected from among these brands as follows: water bottled 1 month ago, water bottled 3 months ago, water expired 1 month ago, water exposed to sunlight and water after freezing. Then, the TOC contents in these samples were measured. The seasonal changes of the TOC contents in all the three factories were assumed to be zero. The residual amount of TOC level difference at the end of the consumption period of the level of this component after bottling was attributed to the effect of the expiration of the consumption period under the storage conditions in Iran's markets. The difference between the aforementioned level and TOC level before bottling was attributed to the overall effect of bottling of water in PET containers during the consumption period.

The TOC test method was conducted according to the standard set of 5310 in the book of the standard methods for the examination of water and wastewater (32) and in accordance with the guidelines mentioned in the book of physico-chemical tests to control water quality (1). The sample size was 0.5 liter according to the TOC instructions put forth by the department of water resources of the TCEQ (30). The number of samples was determined according to the available facilities and with the assumption that some slight changes might occur in the volume of input water to the process and using the description of the sampling plan contained in the TOC guidelines of the water resources department of the TCEQ (30).

\section{Results and Discussion}

Three samples were taken from the water resources of three different brands, including Aquafina, Nestlé Pure Life and Damavand, before bottling. Two samples were taken from each brand: the first samples were taken from among the bottles filled at the same day, and the second samples were taken from the bottles that would expire in a few days. The levels of TOC contents in the samples were measured on the last day of expiration date. In the last step, the samples expired at least one week ago were analyzed for TOC. The results are shown in Tables 1 to 6.

Table 1. Results of TOC $(\mathrm{mg} / \mathrm{L})$ in bottled water.

\begin{tabular}{|c|c|c|c|c|}
\hline Brand & Before bottling & One day after bottling & One month after bottling & Three months after bottling \\
\hline Damavand & 1.37 & 1.69 & 2.11 & 2.14 \\
\hline Nestlé Pure Life & 1.86 & 1.92 & 2.26 & 2.33 \\
\hline Aquafina & 1.55 & 1.77 & 2.18 & 2.21 \\
\hline
\end{tabular}

In pre-bottled samples, the TOC level was about 1.6, but after three months the level of TOC changed significantly. Table 2 shows the extent of changes in TOC at the time of expiration and after that, experiencing environmental stresses, exposed to sunlight and after freezing.

Table 2. Results of TOC $(\mathrm{mg} / \mathrm{L})$ in bottled water.

\begin{tabular}{lllll}
\hline Brand & Near expiration date & One month after expiration & Exposed to sunlight & After freezing \\
\hline Damavand & 2.89 & 3.07 & 4.97 & 4.22 \\
Nestlé Pure Life & 2.91 & 2.97 & 5.25 & 4.15 \\
Aquafina & 3.06 & 3.21 & 5.14 & 3.89 \\
\hline
\end{tabular}

The results indicate that there has not been a dramatic change compared to the results of one month after bottling. However, it seems that time is an effective factor. The results of table 2 show that the TOC level in samples increases as the expiration date approaches. The results of the sampling and analysis one month after the expiration date indicate that the TOC level is higher than before the expiration date. The results of the sampling and analysis of samples after freezing indicate the effect of environmental conditions on the amount of TOC. 


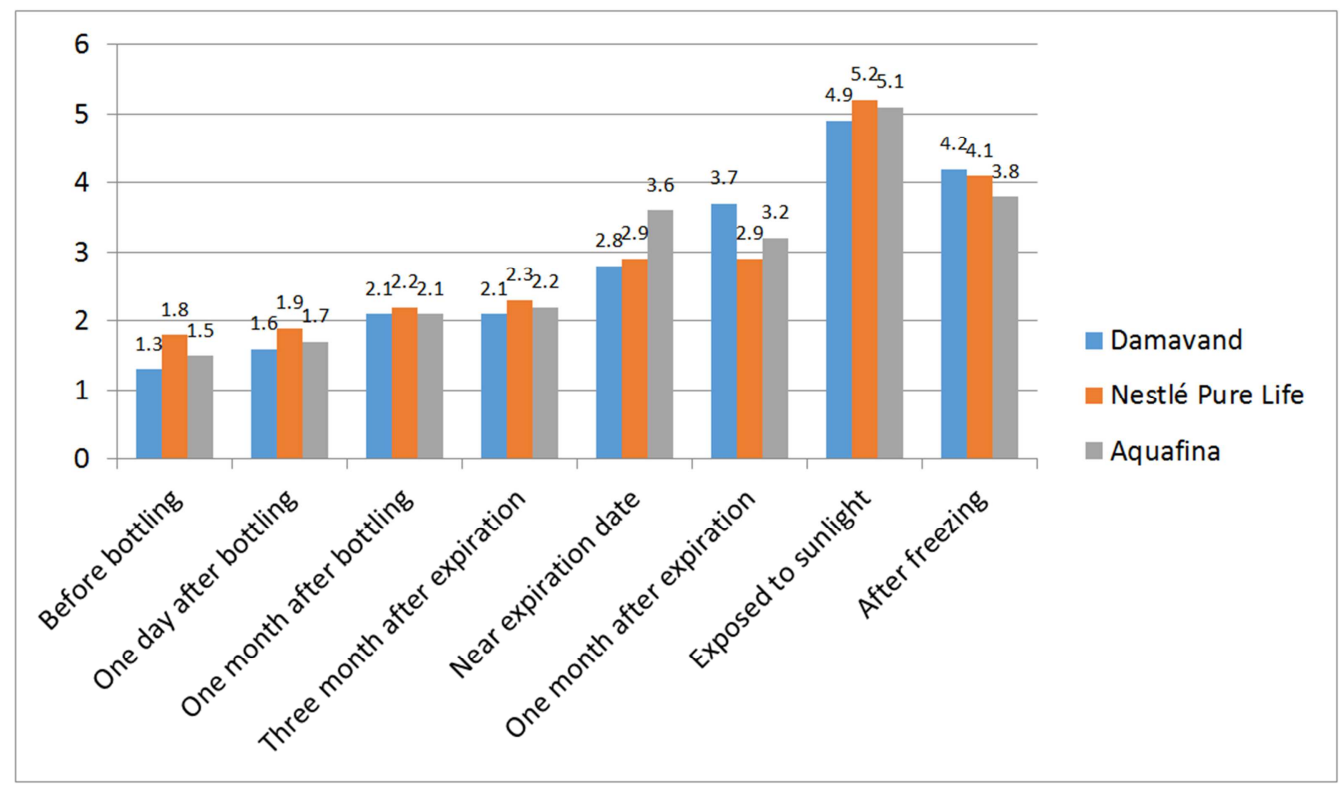

Figure 1. Results of TOC $(\mathrm{mg} / \mathrm{L})$ in bottled water under environmental stresses.

Table 3. Results of TOC $(\mathrm{mg} / \mathrm{L})$ in the waters bottled in winter.

\begin{tabular}{llll}
\hline Brand & Before bottling & After bottling & In distribution and consumption place \\
\hline Damavand & 1.37 & 1.54 & 2.26 \\
Nestlé Pure Life & 1.86 & 1.88 & 2.47 \\
Aquafina & 1.55 & 1.68 & 2.54 \\
\hline
\end{tabular}

The value tested in Table 3 shows very little change after bottling. TOC level increases after expiration date and during the final distribution. Damavand mineral water showed more changes compared to the other two brands.

Table 4. Results of TOC $(\mathrm{mg} / \mathrm{L})$ in the waters bottled in spring.

\begin{tabular}{llll}
\hline Brand & Before bottling & After bottling & In distribution and consumption place \\
\hline Damavand & 1.51 & 1.61 & 2.19 \\
Nestlé Pure Life & 1.76 & 1.85 & 2.51 \\
Aquafina & 1.68 & 1.72 & 2.49 \\
\hline
\end{tabular}

The results of sampling for the second time indicated that there is no change in the level of TOC during bottling in the hot season, but time passing is still an effective factor in increasing the amount of TOC (Tables 4 and 5).

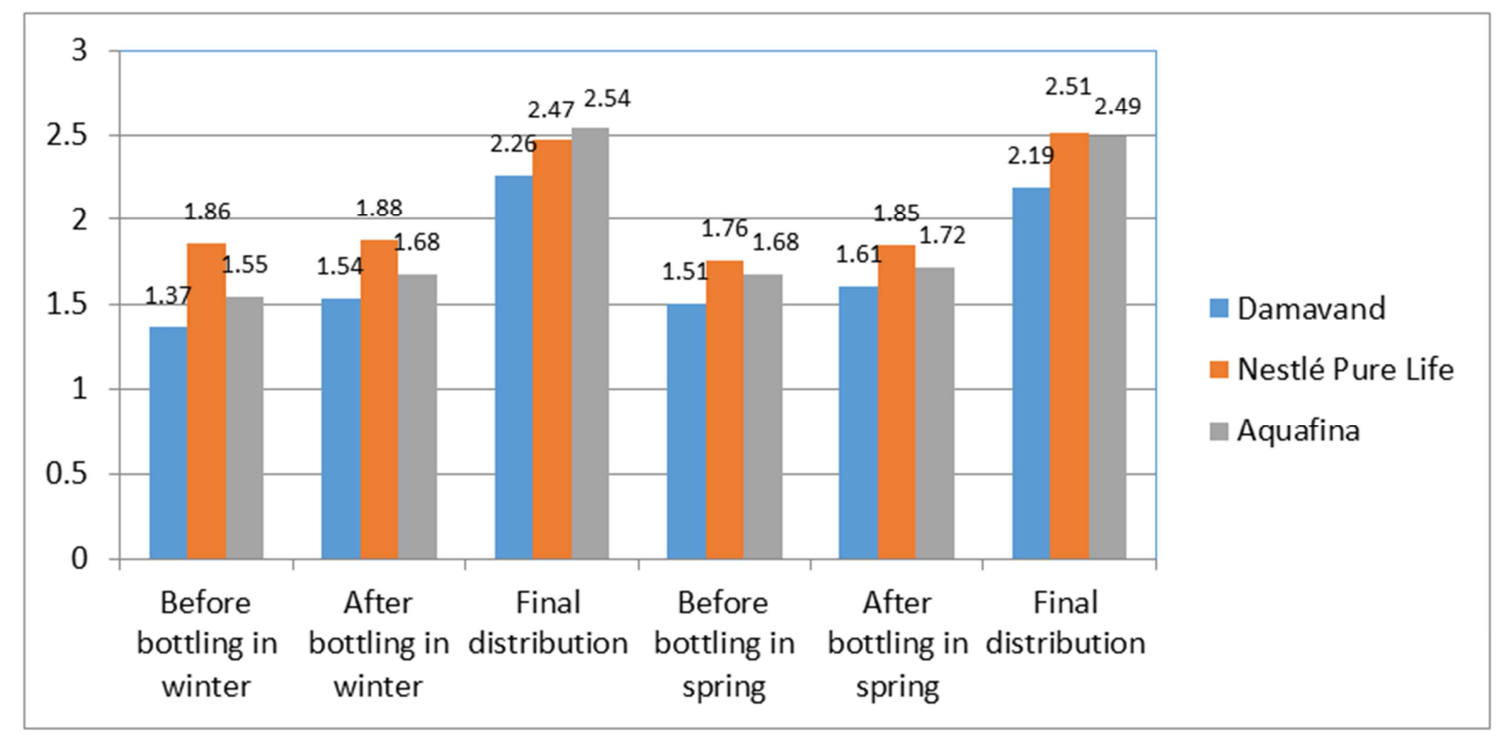

Figure 2. Results of TOC $(\mathrm{mg} / \mathrm{L})$ in the waters bottled in spring and winter. 
Table 5. Results of TOC (mg/L) in waters bottled in summer.

\begin{tabular}{llll}
\hline Brand & Before bottling & After bottling & In distribution and consumption place \\
\hline Damavand & 1.48 & 1.69 & 2.91 \\
Nestlé Pure Life & 1.65 & 1.86 & 3.08 \\
Aquafina & 1.62 & 1.77 & 3.11 \\
\hline
\end{tabular}

Table 6. Results of TOC ( $\mathrm{mg} / \mathrm{L})$ in waters bottled in autumn.

\begin{tabular}{llll}
\hline Brand & Before bottling & After bottling & In distribution and consumption place \\
\hline Damavand & 1.25 & 1.59 & 2.24 \\
Nestlé Pure Life & 1.32 & 1.88 & 2.47 \\
Aquafina & 1.36 & 1.91 & 2.59 \\
\hline
\end{tabular}

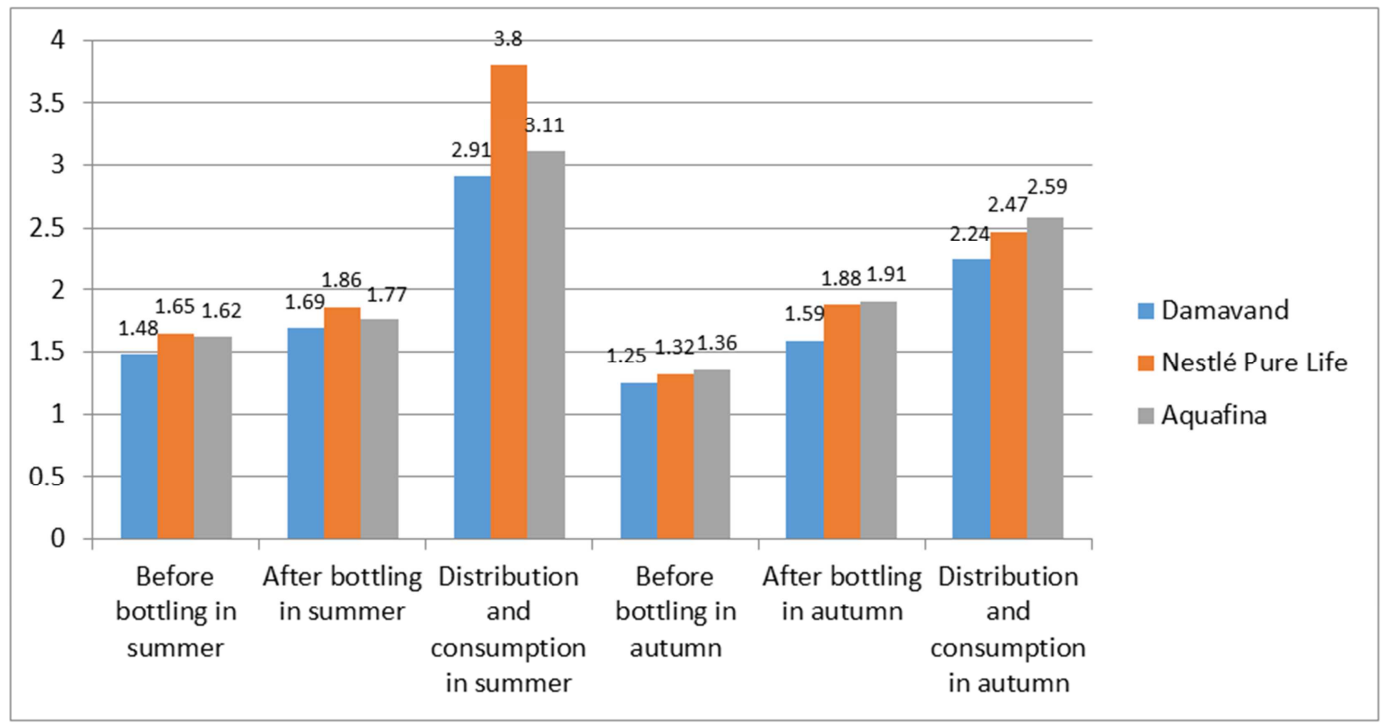

Figure 3. Results of TOC $(\mathrm{mg} / \mathrm{L})$ in the waters bottled in summer and autumn.

Statistical Analysis of the Results

The standard deviation and variance of the data were analyzed for all three samples before and after bottling and at different dates, including near expiration and after expiration dates. Also, the significance level of the results was determined by T-test.

Table 7. Statistical analysis of winter and spring results.

\begin{tabular}{|c|c|c|c|c|}
\hline \multirow{2}{*}{ Brand } & \multicolumn{2}{|l|}{ Winter } & \multicolumn{2}{|l|}{ Spring } \\
\hline & Standard deviation & Variance & Standard deviation & Variance \\
\hline Damavand & 0.6780 & 0.3390 & 0.3672 & 0.1836 \\
\hline Nestlé Pure Life & 0.3466 & 0.1733 & 0.4384 & 0.2192 \\
\hline Aquafina & 0.5380 & 0.2690 & 0.4565 & 0.2283 \\
\hline
\end{tabular}

Table 8. Analysis of t-test results.

\begin{tabular}{|c|c|c|c|c|c|c|c|c|}
\hline & \multicolumn{2}{|c|}{$95 \%$ Confidence Interval of the Difference } & \multirow{2}{*}{$\begin{array}{l}\text { Sig. (2- } \\
\text { tailed) }\end{array}$} & \multirow{2}{*}{ Df } & \multirow{2}{*}{ t } & \multirow{2}{*}{$\begin{array}{l}\text { Standard } \\
\text { deviation error }\end{array}$} & \multirow{2}{*}{$\begin{array}{l}\text { deviation } \\
\text { error }\end{array}$} & \multirow{2}{*}{$\begin{array}{l}\text { Number of } \\
\text { samples }\end{array}$} \\
\hline & Lower & Upper & & & & & & \\
\hline before bottling & 1.518 & 1.785 & 0.0042 & 6 & 5.385 & 0.3654 & 0.8433 & 24 \\
\hline After bottling & 1.623 & 1943 & 0.0042 & 6 & 5.432 & 0.2850 & 0.7986 & 24 \\
\hline One month after bottling & 2.119 & 2.256 & 0.0041 & 6 & 5.615 & 0.3215 & 0.82145 & 24 \\
\hline Three months after bottling & 2.135 & 2.339 & 0.0038 & 6 & 5.455 & 0.3516 & 0.8079 & 24 \\
\hline Near expiration date & 2.786 & 3.041 & 0.0036 & 6 & 5.189 & 0.3417 & 0.8275 & 24 \\
\hline One month after expiration & 2.968 & 3.206 & 0.0031 & 6 & 5.344 & 0.3246 & 0.8119 & 24 \\
\hline Exposed to sunlight & 5.02 & 5.452 & 0.0018 & 6 & 5.253 & 0.3084 & 0.7986 & 24 \\
\hline After freezing & 3.981 & 4.297 & 0.0024 & 6 & 5.187 & 0.3124 & 0.8216 & 24 \\
\hline Before bottling in all seasons & 1.0614 & 1.864 & 0.003 & 4.65 & 5.477 & 0.36515 & 0.89433 & 36 \\
\hline After bottling in all seasons & 1.471 & 1.869 & 0.0032 & 4.74 & 5.341 & 0.32145 & 0.89511 & 36 \\
\hline $\begin{array}{l}\text { In consumption place in all } \\
\text { seasons }\end{array}$ & 2.142 & 2.9386 & 0.0029 & 4.12 & 5.215 & 0.33218 & 0.89145 & 36 \\
\hline
\end{tabular}

Considering the scores of standard deviation and variance of the data and t-test, the significance level is lower than 0.5 
which shows that there is a meaningful relationship between time and amount of TOC. Also, the significance level should be less than 0.5 in order to show a meaningful difference between initial and final data. In addition, all samples were between 0.0018 and 0.0041 , which is not in the domain of significance level (Table 8).

\section{Conclusion}

The results of the sampling and analysis of bottled water from three mineral water plants in Tehran showed that the level of TOC in mineral water increased over time. Examples that were analyzed after the expiration date indicated significant changes. But the study of mineral water showed that the level of TOC is standard and there is no problem in this regard. But environmental stresses such as sunlight had a significant effect on the water. The analysis of frozen water showed that the TOC level increases after freezing.

Studying the level of TOC in water after bottling showed that water changes slightly one day after bottling. But after one and three months, these changes became gradually more significant, in a way that the level of TOC increased from about 1.6 to $2.33 \mathrm{mg} / \mathrm{L}$.

Near expiration date: in the study of the waters close to their expiration dates, it was observed that the TOC level was nearly doubled from 1.6 to $2.9 \mathrm{mg} / \mathrm{L}$, which is significant. The study of TOC level in expired bottled water showed that TOC level increased from 1.6 to $3.2 \mathrm{mg} / \mathrm{L}$.

When the samples were exposed to sunlight, the TOC level was about four times and reached $5.47 \mathrm{mg} / \mathrm{L}$. This can be a great warning for wholesalers and retailers to avoid storing and exposing bottled waters to the sunlight.

Studying the level of TOC in mineral water after freezing showed significant changes, in a way that the TOC level increased from 1.6 to $4.11 \mathrm{mg} / \mathrm{L}$, which is three times more than the initial value. This means that stores selling frozen water should be warned seriously.

Also, the significance level should be less than 0.5 in order to show a meaningful difference between initial and final data. In addition, all samples were between 0.0018 and 0.0042 , which is not in the domain of significance level.

\section{References}

[1] Bieroza Magdalena Zofia CHARACTERISING WATER TREATMENT WORKS PERFORMANCE USING FLUORESCENCE SPECTROSCOPY [Report]: PHD Dissertation / Civil Engineering; The University of Birmingham. - Birmingham: The University of Birmingham, 2009. - pp. 1-285.

[2] Bittner George D. [et al.] Chemicals having estrogenic activity can be released from some bisphenol a-free, hard and clear, thermoplastic resins [Journal] // Environmental Health. - [s.l.]: BioMed Central. - 103: Vol. 13. - pp. 1-18.

[3] Monarca S. [et al.] Studies of Migration of Potentialy Genotoxic Componds into Water Stored in PET Bottles [Journal] // Fd. Chem. Toxic.. - [s.l.]: Elsevier Sci. Comp. Pergamon., 1994. - 9: Vol. 32. - pp. 783-788.

[4] Bourgeois Wilfrid, Burgess Joanna E and Stuetz Richard M On-line monitoring of wastewater quality: a review [Journal] // J Chem Technol Biotechnol. - 2001. - Vol. 76. - pp. 337-348.

[5] Farhadkhani Marzieh [et al.] Assessment of drinking water quality from bottled water coolers [Journal] // Iranian Journal of Public Health. - 2014. - 5: Vol. 43. - pp. 647-681.

[6] Carneado S. [et al.] Migration of antimony from polyethylene terephthalate used in mineral water bottles [Journal] // Food Chemistry. - [s.1.]: Elsevier Ltd., 2015. - Vol. 166. - pp. 544550 .

[7] Sulaiman G. Muhammad, Lawen S. Esmail and Shelear H. Hasan Effect of storage temperature and sunlight exposure on the physicochemical properties of bottled water in Kurdistan region-Iraq [Journal] // J. Appl. Sci. Environ. Manage.. - [s.1.]: bioline, 2011. - 1: Vol. 15. - pp. 147-154.

[8] Warburton Donald W. [et al.] A review of the microbiological quality of bottled water sold in Canada between 1981 and 1989 [Journal] // Can. J. Microbiol. - 1992. - Vol. 38. - pp. 1219.

[9] Warburton Donald W. A review of the microbiological quality of bottled water sold in Canada. Part 2. The need for more stringent standards and regulations [Journal] // Can. J. Microbiol. - 1993. - Vol. 39. - pp. 158-168.

[10] WHO Guidelines for drinking-water quality [Report]. - Malta: World Health Organization, 2011. - pp. 1-509. 